\title{
Age-Sex Related in Hematological Values of Sandalwood Pony Horses (Equus caballus) in East Sumba, NTT
}

\author{
Cynthia Dewi Gaina ${ }^{1}$, Antin Y. N. Widi ${ }^{2}$, Agus Saputra ${ }^{3}$ \\ ${ }^{1}$ Division of Clinic, Reproduction, Pathology and Nutrition, \\ Faculty of Veterinary Medicine, Nusa Cendana University, Indonesia \\ Email: cynthia.gaina@staf.undana.ac.id \\ ${ }^{2}$ Division of Clinic, Reproduction, Pathology, Nutrition, \\ Faculty of Veterinary Medicine, Nusa Cendana University, Indonesia \\ Email: antin.widi@my.jcu.edu.au \\ ${ }^{3}$ Division of Anatomy, Physiology, Pharmacology, Biochemistry \\ Faculty of Veterinary Medicine, Nusa Cendana University, Indonesia \\ Email: agus_ketchup@yahoo.com
}

Corresponding Author: cynthia.gaina@staf.undana.ac.id

\begin{abstract}
Normal hematological values need to be defined for each category of horse, like age and sex to obtain precise diagnostic results. No published data on hematology exist for Sandalwood horses that are extensively reared in East Sumba, NTT. The main objective of this research was to compare the hematological characteristic of horse group based on age and sex. Blood samples from sixteen horses were collected based on sex into male $(n=6)$, female $(n=10)$ and age groups of 2-3 years $(n=4)$ and 6-10 years old $(n=12)$. About $3 \mathrm{ml}$ of blood sample was collected aseptically from jugular vein of each of these animals in sterile vacutainer tube. The following variables were measured: erythrocyte, leucocyte, platelet, hemoglobin $(\mathrm{Hb})$, hematocrit $(\mathrm{HCT})$, mean corpuscular volume (MCV), mean corpuscular hemoglobin $(\mathrm{MCH})$, mean corpuscular hemoglobin concentration (MCHC) and mean platelet volume (MPV). These hematological parameters were calculated with the automatic hematology analyzer at Health Laboratory in Kupang, NTT. This result was analyzed by using student T-test and analysis of variance. These results would contribute to better understanding of the hematological indicators for estimating the physiological status of Sandalwood horse in East Sumba as it can be used as valuable information of its health physiological status.
\end{abstract}

Keywords: East, Hematological value, Horse, Sandalwood, Sumba

\section{I.INTRODUCTION}

The Sandalwood pony originated in Sumba Island, Indonesia which has great amount of Arabian blood. This horse has good endurance and has been bred only in Sumba Island according to
KEMENTAN No. 43/Kpts/PD.010 /1/2015 [1]. Although, Sandalwood pony has been known for its racing ability, limited information about its hematological values has been provided. Hematological parameters in horses are one of the clinical diagnosis 
tools for measuring physiological status. Interpretation of diagnostic parameters is important to determine the specific breeds and the relevant age groups. The blood profile can be affected by their age, sex, breed, temperament and blood type [2]. Blood component reflect situation in an organ or body system which is a common response of the individual animal to physiological or pathological conditions [3]. The hematological values provide beneficial information that could assist farm management practices, nutritional and physiological status of animals and health condition [4]. The hematological parameters, such as red blood count cells (RBC) or erythrocytes counts, erythrocytes indices, leucocytes, platelets and platelets indices are affected by age, sex, seasonal variation, lactation, pregnancy, health and nutrition [5]. The erythrocytes counts includes erythrocytes, hematocrit, hemoglobin, while erythrocytes indices includes mean corpuscular volume (MCV), mean corpuscular hemoglobin $(\mathrm{MCH})$ and mean corpuscular hemoglobin concentration and mean platelet volume (MPV) that is an index for assessing platelet indices [6]. These results hopefully would contribute to be used in sport or racing horse, like
Sandalwood horse for measuring their physiological status

\section{II.MATERIAL AND METHODS}

While collecting blood samples, adequate precautionary measures were taken to minimize pain and discomfort to the animals and samples collection was carried out in accordance with the guidelines laid down by the Animal Ethics Committees in Nusa Cendana University with the series number KEH/FKH/NEPH/014/2019. This study was undertaken at local farm in East Sumba. A total of sixteen horses were used in study. Blood samples from sixteen horses were collected based on sex into male $(n=6)$, female $(n=10)$ and age groups of 2-3 years $(n=4)$ and 6-10 years old $(n=12)$. About $3 \mathrm{ml}$ of blood sample was collected aseptically from jugular vein of each of these animals in sterile vacutainer tube. Blood samples were used to identify red blood cells, white blood cells, platelet, hemoglobin (Hb), hematocrit (HCT), mean corpuscular volume (MCV), mean corpuscular hemoglobin $(\mathrm{MCH})$, mean corpuscular hemoglobin concentration (MCHC) and mean platelet volume (MPV). These hematological parameters were calculated with the automatic hematology analyzer at 
Health Laboratory in Kupang. This result was analyzed by using student $\mathrm{T}$ test and analysis of variance.

\section{III.RESULT AND DISCUSSION}

\section{Result}

In this study, Table 1 showed that erythrocytes, platelets, hemoglobin, hematocrit and $\mathrm{MCH}$ and $\mathrm{MCHC}$ level were significantly different $(\mathrm{p}<0.05)$ between male and female groups. The leucocytes, MCV and MPV level did not differ significantly $(\mathrm{p}>0.05)$ between male and female groups. The leucocytes and platelets level in pregnant female were lower compare with other groups and normal standard, while MCHC level was lower in three sex groups compare with the standard. On the other hand, hematocrit and MCV level were higher in all sex groups compare with the normal values

Table 1. Hematological parameters in Sandalwood pony horses (Equus cabalus) based on the sex in comparison to the normal physiological range [7]

\begin{tabular}{|c|c|c|c|c|c|}
\hline \multirow[t]{2}{*}{ Blood parameters } & \multirow{2}{*}{$\begin{array}{l}\text { Normal } \\
\text { physiological } \\
\text { range }\end{array}$} & \multicolumn{4}{|c|}{ Group (mean+SEM) } \\
\hline & & male $(n=6)$ & female $(n=6)$ & $\begin{array}{l}\text { pregnant female } \\
(\mathrm{n}=4)\end{array}$ & $p$ values \\
\hline $\begin{array}{l}\text { Erythrocytes / RBCs } \\
\left(10^{6} / \mu \mathrm{l}\right)\end{array}$ & $5.00-10.00$ & $9.00 \pm 0.365^{*}$ & $9.50 \pm 0.922 *$ & $7.00 \pm 0.707^{*}$ & 0.090 \\
\hline Leucocytes $\left(10^{3} / \mu 1\right)$ & $5.6-12.1$ & $6.17 \pm 0.946$ & $5.17 \pm 1.249$ & $3.00 \pm 0.000$ & 0.156 \\
\hline Platelets $\left(10^{3} / \mu \mathrm{l}\right)$ & $117-256$ & $217.83 \pm 35.427 *$ & $153.17 \pm 14.773 *$ & $15.75 \pm 0.750^{*}$ & 0.000 \\
\hline Hemoglobin (g/dl) & $10.1-16.1$ & $14.83 \pm 0.703^{*}$ & $15.50 \pm 1.408^{*}$ & $11.50 \pm 1.323^{*}$ & 0.095 \\
\hline Hematocrit (\%) & $27-43$ & $56.33 \pm 3.739 *$ & $61.67 \pm 5.364^{*}$ & $44.50 \pm 4.975^{*}$ & 0.088 \\
\hline $\begin{array}{l}\text { Mean corpuscular } \\
\text { volume (fl) }\end{array}$ & $37-49$ & $60.00 \pm 1.366$ & $60.67 \pm 1.022$ & $59.50 \pm 1.555$ & 0.828 \\
\hline $\begin{array}{l}\text { Mean corpuscular } \\
\text { hemoglobin }(\mathrm{pg})\end{array}$ & $13.7-18.2$ & $16.50 \pm 0.563 *$ & $14.83 \pm 0.307 *$ & $15.00 \pm 0.408^{*}$ & 0.035 \\
\hline $\begin{array}{l}\text { Mean corpuscular } \\
\text { hemoglobin } \\
\text { concentration }(\mathrm{g} / \mathrm{dl})\end{array}$ & $35.3-39.3$ & $27.33 \pm 0.422 *$ & $25.50 \pm 0563 *$ & $26.25 \pm 0.479 *$ & 0.052 \\
\hline $\begin{array}{l}\text { Mean platelet volume } \\
\text { (fl) }\end{array}$ & $4.0-6.0$ & $5.50 \pm 0.619$ & $6.00 \pm 0.577$ & $4.75 \pm 0.479$ & 0.393 \\
\hline
\end{tabular}

*Values within the same row differ significantly with different exponent $(p<0.05)$

Based on age categories, it showed that the MCH and MPV level were significantly different in these two groups $(p<0.05)$, while the other parameters were not significantly different $(\mathrm{p}>0.05)$. The results showed that the level of MCV and MCHC were lower, while the HCT level was higher compare with normal standard of hematological values in horses. 
Table 2. Hematological parameters in Sandalwood pony horses (Equus cabalus) based on the age in comparison to the normal physiological range [7]

\begin{tabular}{|c|c|c|c|c|}
\hline \multirow[t]{2}{*}{ Blood parameters } & \multirow{2}{*}{$\begin{array}{l}\text { Normal } \\
\text { physiological } \\
\text { range }\end{array}$} & \multicolumn{3}{|l|}{ Group (mean+SEM) } \\
\hline & & Age 2-3 years $(n=4)$ & $\begin{array}{l}\text { Age 6-10 years } \\
(\mathrm{n}=12)\end{array}$ & $p$ values \\
\hline Erythrocytes $\left(10^{6} / \mu 1\right)$ & $5.00-10.00$ & $8.50 \pm 0.289$ & $8.75 \pm 0.617$ & 0.824 \\
\hline Leucocytes $\left(10^{3} / \mu \mathrm{l}\right)$ & $5.6-12.1$ & $6.00 \pm 0.913$ & $4.67 \pm 0.791$ & 0.385 \\
\hline Platelets $\left(10^{3} / \mu \mathrm{l}\right)$ & $117-256$ & $229.25 \pm 47.943$ & $177.08 \pm 14.218$ & 0.169 \\
\hline Hemoglobin (g/dl) & $10.1-16.1$ & $14.50 \pm 0.645$ & $14.17 \pm 0.999$ & 0.856 \\
\hline Hematocrit (\%) & $27-43$ & $55.50 \pm 4.805$ & $55.33 \pm 3.911$ & 0.982 \\
\hline $\begin{array}{l}\text { Mean corpuscular } \\
\text { volume (fl) }\end{array}$ & $37-49$ & $60.00 \pm 1.958$ & $60.17 \pm 0.747$ & 0.923 \\
\hline $\begin{array}{l}\text { Mean corpuscular } \\
\text { hemoglobin }(\mathrm{pg})\end{array}$ & $13.7-18.2$ & $16.25 \pm 0.946$ & $15.25 \pm 0.279$ & 0.179 \\
\hline $\begin{array}{l}\text { Mean corpuscular } \\
\text { hemoglobin } \\
\text { concentration }(\mathrm{g} / \mathrm{dl})\end{array}$ & $35.3-39.3$ & $28.00 \pm 0.408 *$ & $25.83 \pm 0.297 *$ & 0.002 \\
\hline $\begin{array}{l}\text { Mean platelet volume } \\
\text { (fl) }\end{array}$ & $4.0-6.0$ & $6.50 \pm 0.645^{*}$ & $5.17 \pm 0.366^{*}$ & 0.091 \\
\hline
\end{tabular}

*Values within the same row differ significantly with different exponent $(p<0.05)$

\section{Discussion}

In this study, hematology values of Sandalwood horse which extensively reared in East Sumba showed similarity with the normal standard of hematologic parameters in horses based on Table 1 and 2 [7]. One of the hematological parameters was the HCT, also called the packed cell volume (PCV), which is the percentage of the whole blood that consist of red cells which refers to anemia condition when the level of HCT is lower than normal value. However, this research showed there was an increasing level of HCT compare with standard values that might indicate dehydration. A higher level of HCT also correlates with an increase of the circulation of red blood cells that might be caused by an exercise induced contraction because the circulating RBCs increase the oxygen store and the oxygen carrying capacity [8]. Change in hemoglobin $(\mathrm{Hb})$ concentration in blood will change the oxygen capacity [9] because $\mathrm{Hb}$ depends on both the mean corpuscular hemoglobin concentration (MCHC) and the HCT. An increase of MCHC is usually correlated with hemolysis that is caused by either result of disease or improper sample handling, while a decreased level of $\mathrm{MCHC}$ and $\mathrm{MCH}$ indicates iron deficiency [10].

Another parameter of this hematologic value is platelets. Platelets play an essential role in hemostasis and in preventing inflammatory and 
immunological reactions [11]. This result showed that a decreased level of platelets might be caused by age and pregnancy status. As it is said that platelet numbers do not change in foals during the first year of life, but it decreases throughout the years of life $[12,13]$. The results showed similarity of platelet level in Sandalwood pregnant mares with Carthusian broodmares that has a significantly decline in platelet numbers during pregnancy [14]. It might be affected by stress and hormone, such as estrogen, progesterone and other steroid hormones during pregnancy [15]. One of the hematologic parameters relates to platelet counts is mean platelet volume (MPV). The MPV is average volume of a single platelet in femtoliters (fl) [15]. Although it is rare to obtain high level of MPV in horses, a high MPV suggests an increased thrombopoiesis or production of platelet that participate in coagulation and in inflammatory conditions [15].

In addition, another value is the mean corpuscular volume (MCV). It is measured to obtain the average size of each red blood cell sample that the normal range for horses is 37.0 to 49.0 femtoliters. Most of red blood cells in normal horse are about in the same size. However, it can define as potential problems if it varies in size. If MCV is lower than normal value, it indicates microcytic anemia, while if MCV is higher than standard, it is diagnosed as macrocytic anemia [16]. Hematological differences associates with sex were subjected to controversy, for example other breed of stallion have slightly higher RBC,HB and PCV while females have higher $\mathrm{MCH}$ and $\mathrm{MCHC}$, whereas Quarter horses showed results that was similar with Sandalwood horse in this research that $\mathrm{RBC}, \mathrm{PCV}$ and $\mathrm{Hb}$ were higher in mares than in stallion [3].

\section{CONCLUSIONS}

In this study, it is concluded that the hematological values of the Sandalwood horse were affected by sex and age. Thus, the data presented in this study could be served baseline information for diagnosing physiological or pathological conditions of similar horses' type.

\section{REFERENCES}

[1] Gaina, C. D., \& Foeh, N. D. (2018). Studi Performa Umum Tubuh dan Status Fisiologis Kuda Sumba (Study of Body Performance and 
Physiological Status of Sumba Horse). Jurnal Kajian Veteriner, 6(2), 38-44.

[2] Miknienè, Z., Maslauskas, K., Kerzienè, S., Kučinskienè, J., \& Kučinskas, A. (2013). The effect of age and gender on blood haematological and serum biochemical parameters in Žemaitukai horses. Veterinarija ir zootechnika, 65(87).

[3] Satué, K., Hernández, A., \& Muñoz, A. (2012). Physiological factors in the interpretation of equine hematological profile. In Hematology-science and practice. IntechOpen.

[4] Osman, T. E. A., \& Al-Busadah, K. A. (2003). Normal concentrations of twenty serum biochemical parameters of shecamels, cows and ewes in Saudi Arabia. Pakistan Journal of Biological Sciences, 6(14), 1253-1256.

[5] Sattar, A., \& Mirza, R. H. (2009). Hematological parameters in exotic cows during gestation and lactation under subtropical conditions. Pakistan veterinary journal, 29(3), 129-132.

[6] Kocaturk, M., Yesilbag, K., \& Yilmaz, Z. (2010). Evaluation of red blood cell and platelet indices in cattle naturally infected with bovine viral diarrhea virus (BVDV). Uludag Univ J Fac Vet Med, 29(1), 1721.

[7] Susan E. F. 2015. Hematological Reference Ranges. https://www.msdvetmanual.com /SearchResults?query=hematolo gic+reference [10 October 2019]

[8] Windberger, U., Pöschl, C., Peters, S., Huber, J., \& Van den Hoven, R. 2017. Measurement of whole blood of different mammalian species in the oscillating shear field: influence of erythrocyte aggregation. In Journal of Physics: Conference Series (Vol. 790, No. 1, p. 012035). IOP Publishing.

[9] Powell, F. L. (2015). Chapter 13Respiration. Sturkie's Avian Physiology, Academic Press. 301-336.

[10] Meindel, M.J Wilkerson, M.J 2015. Chapter 112 - Anemia, Robinson's Current Therapy in Equine Medicine (Seventh Edition), W.B. Saunders, 471475

[11] Satué, K., Gardón, J. C., \& Muñoz, A. (2017). Interpretation of platelets in the horse. $J$ Hematol Res, 4, 19-25.

[12] Segura D, Monreal L, Pérez-Pujol S, Pino M, Ordinas A. 2006 Assessment of Platelet Function in Horses: Ultrastructure, Flow Cytometry, and Perfusion Techniques. J Vet Int Med; 20(3): 581-588. https://doi.org/10.1111/j.19391676.2006.tb02900.x

[13] Satue, K., Blanco, O., \& Munoz, A. (2009). Age-related differences in the hematological profile of Andalusian broodmares of Carthusian strain. Veterinarni Medicina, 54(4), 175-182.

[14] Satué K, Mu-oz A and Blanco O. (2010). Pregnancy influences the hematological profile of Carthusian broodmares. Polish J Vet Sci; 3(2): 393-394.

[15] Harvey, J.W. 2012. Chapter 1 Introduction to Veterinary Hematology, Veterinary Hematology, W.B. Saunders, 2012, p 1-10, ISBN 9781437701739, 
Journal of Veterinary and Animal Sciences

DOI: https://doi.org/10.24843/JVAS.2020.v03.i02.p06

https://doi.org/10.1016/B978-14377-0173-9.00001-4.

[16] Dasgupta, A. (2015). Alcohol and Its Biomarkers: Clinical
pISSN 2550-1283; elSSN:2622-0571

August 2020 Vol. 3 No.2: 103-109

Aspects and Laboratory Determination.

https://doi.org/10.1016/C2013-

0-18538-8 